\title{
“ANTES DE QUESTÕES DE STATUS FINAL, É PRECISO FALARMOS DE UMA NEGOCIAÇÃO DE PAZ PRODUZIDA PELO RECONHECIMENTO E PELA IMPLEMENTAÇÃO DE DIREITOS HUMANOS"
} Entrevista da Prof. Dra. Arlene Clemesha à revista Malala ${ }^{1}$

Revista Malala: Geralmente um ponto de partida de nossas entrevistas é falarmos sobre a formação de nosso entrevistado. A senhora possui experiência na área de História, com ênfase em História Contemporânea, atuando principalmente com História da Palestina, árabe e com a própria questão palestina. Poderia falar um pouco mais sobre a sua trajetória?

Arlene Clemesha: Então, para que fique registrado, nós combinamos que falaremos "você" (risos). Bom, eu sou formada em História com toda a minha pesquisa na área de História, mestrado e doutorado, e a minha trajetória realmente foi em busca de respostas para este que é um dos grandes conflitos mundiais hoje, que é o conflito israelo-palestino. Comecei os meus estudos não só atrás do conflito, mas interessada também em questões de opressão, emancipação, estimagtização, racismo e traços como estes que estão tão presentes nos conflitos hoje. Então meu mestrado, ou minhas primeiras pesquisas ainda na graduação na verdade, foram sobre a questão judaica, e meu mestrado foi todo em pesquisas relacionadas à questão judaica, visões sobre a questão judaica e movimentos sociais que buscavam a emancipação dos judeus antes mesmo da origem do sionismo. E no doutorado é que eu parti para a questão palestina,

\footnotetext{
${ }^{1}$ Entrevista realizada no dia 30 de Janeiro de 2015 por Natalia Nahas Calfat e Danilo Guiral Bassi.
} 
não só a questão palestina, mas um contexto na verdade mundial um pouco mais amplo, ou seja, a Segunda Guerra Mundial, a criação de Israel e o conflito árabe-israelense.

R.M.: Você é professora doutora do Departamento de Letras Orientais (FFLCH) da Universidade de São Paulo, atual Diretora do Centro de Estudos Árabes da USP e membro do comitê de coordenação do United Nations International Coordinating Network on Palestine (ICNP-UN). Como esta atuação docente influencia na formação de novos pesquisadores dentro desta área e trabalhando com estes temas? Qual a sua preocupação inicial ao formar estes novos pesquisadores?

A.C.: A minha preocupação enquanto professora da USP e diretora do Centro de Estudos Árabes é, mais que nada, permitir que os alunos possam desenvolver os temas de seu interesse e buscando as fontes e os métodos do seu interesse. Então eu não busco guiar nada, absolutamente nada (risos). Eu não acredito muito na influência de orientador sobre aluno - aliás, eu não acredito nada. Eu acho que os alunos são bastante independentes e bastante inteligentes para encontrarem seu caminho. Então o máximo que eu posso fazer é abrir ao máximo as portas que me são possíveis e cabíveis para que os alunos tenham o espaço do curso de árabe para sua formação. 0 curso de árabe tem uma característica, que é ser um curso de letras, evidentemente. 0 que por um lado permite um trabalho bastante livre em termos de fontes, então os alunos podem reunir as fontes de diversas áreas das humanidades tanto de Letras, como de Relações Internacionais, História principalmente, na verdade, sem necessariamente terem que desenvolver pesquisas em História árabe. Então dentro dos estudos árabes, nós estamos abertos para um leque maior, um leque bastante amplo de pesquisas e de tendências.

R.M.: Você acha que nessa área de estudos e de pesquisa é possível dissociar o conhecimento e a produção científica e acadêmica da ação, atuação e posicionamento políticos?

A.C.: Veja, é possível dissociar e é possível fazer as duas coisas juntamente. Todos os dois quadros, as duas hipóteses são possíveis. Você pode, digamos, dedicar dois anos da sua vida a fazer apenas pesquisa sem ter nenhum tipo de atuação ativista, militante, em grupos de digamos defesa dos direitos palestinos - como eu tenho na ONU, que é uma 
atuação -, como você pode fazer as duas coisas juntas. 0 que você não pode é deixar de ter um posicionamento em relação àquilo que você está estudando. Ou seja, isenção não existe. Você pode ter objetividade e dizer claramente qual é a sua postura. Isso é honestidade intelectual.

R.M.: Sabemos que você contabiliza um número significativo de viagens ao Oriente Médio, Israel e Palestina. Após suas inúmeras experiências, como é sua visão atual do conflito após estas visitas e convivência in loco? Elas mudaram sua percepção do conflito e daquelas sociedades em algum momento?

A.C.: Visitar a Palestina, as universidades na Palestina, as comunidades, tanto cidades, quanto vilarejos, como meios, por exemplo, menos atingidos como beduínos e tudo mais, ou seja, ter este trânsito pela Palestina, é muito importante para conseguir aprofundar a sua percepção e o seu entendimento de tudo aquilo que você pesquisa nos livros. Porque a História vai te trazer um tipo de visão, uma visão que pode ser muito precisa, você pode atingir um grau de percepção, de entendimento, bastante preciso através de uma leitura crítica de diversas fontes sempre variadas. Mas uma visita in loco, este contato, sempre é extremamente importante. Eu não sei se muda, se mudou a minha visão, mas certamente ajudou a aprofundar.

R.M.: Sobre o conflito propriamente dito, na sua perspectiva, faz sentido falarmos em negociações de paz? Tanto hoje quanto no passado. Pode-se estabelecer uma negociação de paz quando há uma relação de poder desigual como sabemos que existe na região?

A.C.: Bom, as primeiras negociações de paz que foram ensaiadas e tentadas foram logo após a Segunda Guerra Mundial e a criação do Estado de Israel - e estas fracassaram. E só foram retomadas na década de 90. E o fracasso mais uma vez de todas estas tentativas poderia nos levar a dizer que não faz sentido falar em negociações de paz. No entanto, faz sentido. Mesmo dentro de uma assimetria de forças, faz sentido buscar as condições para que as negociações de paz possam acontecer. Ou seja, o que não faz sentido é simplesmente abrir mão de qualquer tentativa de negociação de paz. 
R.M.: Na sua perspectiva quais são as precondições estabelecidas pelo Estado de Israel e seus governantes e pelos palestinos e pela Autoridade Palestina em possíveis negociações de paz? Quanto distante estamos de uma possível paz permanente na região?

A.C.: Estamos muito distantes, acredito eu, da possibilidade de uma verdadeira negociação de paz. E o que pode nos aproximar não é nem tanto uma análise das précondições israelenses ou palestinas, mas uma análise da correlação de forças. Então somente uma correlação mais equilibrada e justa de forças é que pode dar resultado. E aí não importa quais sejam as pré-condições ou linhas vermelhas, elas caem e são erguidas a medida em que a negociação acontece. Então esta mudança na correlação de forças é o que precisa acontecer.

R.M.: Você acredita que existam itens para ambas as partes que sejam "negociáveis" e outros "inegociáveis"? Quais são eles? Existe uma linha que estabelece que "a partir daqui não estou disposto a ceder ou abrir mão de determinadas demandas"?

A.C.: Eu poderia responder "as questões de status final", por exemplo, não é? Então: Jerusalém, fronteiras, água e refugiados. Mas existe uma questão que sempre parece que escapa às negociações, que são os direitos humanos. Então, ao invés das negociações serem norteadas e conduzidas pelo respeito aos direitos humanos, elas são deslocadas para outros pontos digamos assim, chamados de questões de status final, e que são importantes. Eu penso mesmo que abrir mão de Jerusalém Oriental é algo que nenhum governo palestino, mesmo com um governo extremamente fraco, poderia fazer. Abrir mão do reconhecimento do direito de retorno, com uma negociação sobre a implementação do direito do mesmo, porque não é algo fácil e ninguém vai ignorar que seja possível de uma hora para outra que o direito de retorno de nem 5 milhões (5 milhões são os refugiados que estão registrados na UNRWA, 4,7 milhões a esta altura, não sei, mas na verdade algumas estimativas contabilizam 9 milhões de refugiados e algumas chegam a 11 milhões de refugiados palestinos, com seus descendentes, não registrados na $\mathrm{ONU}$ ). Bom, então não é uma questão fácil, mas deixar de haver o reconhecimento... Então esta questão de status final ela não está aí à toa, são questões importantes, mas a gente vê que na correlação de forças a questão da fronteira começa a 
flutuar de acordo com a possibilidade de cada lado firmar sua posição. Então dizer que é uma questão de status final é algo também muito abstrato, não é? Qual é realmente a possibilidade de implementação de uma fronteira com base na Linha Verde, com base no Armistício de 1949, que é a linha da invasão de 1967? É essa a questão que a gente se deve perguntar. E depois a questão da exploração de água, então, é algo que é extremamente complexo e que vem acontecendo de uma maneira muito injusta para o lado palestino. Mas dentro de tudo isso, o que a gente vê no fundo é uma população palestina que, em muitos casos, talvez nem se importasse se aquilo tudo fosse chamado de Israel, de Palestina, de Terra Verde, Azul ou Vermelha, conquanto que tivessem condições de vida, que pudessem ir e vir, que pudessem trabalhar. A gente tem mais de 70\% da população da Cisjordânia desempregada, e que, para conseguir trabalhar, por exemplo, em Jerusalém Oriental, enfrenta uma fila de duas horas e meia das cinco às sete e meia da manhã por onde passam em um único check point 5 mil pessoas nesse período, ou seja, mais de setecentas a cada meia-hora. Ou seja, isto não é condição de vida, cadê os direitos humanos? Então, se as condições de vida são resolvidas, aí você tem outro panorama para se falar em acordo de paz. E o que seria um acordo de paz se estas condições de vida e de direitos humanos não forem resolvidas? Ele vai vingar? Vai ser um verdadeiro acordo de paz? Ao invés de falarmos em questões de status final ou, digamos assim, antes, até, de questões de status final, é preciso falarmos de uma negociação produzida pelo reconhecimento e pela tentativa da implementação de direitos humanos. E aí o que precisa para esta implementação? É muito detalhado, mas várias vezes grupos até honestos de pessoas tentaram seriamente sentar para elaborar este tipo de quadro, mas nunca foi para frente.

R.M.: Ainda sobre as possíveis negociações, o Professor Samuel Feldberg, em entrevista concedida ao volume 1 do boletim Malala n. 3 afirmou que "o máximo que Israel está disposto a oferecer não chega ao mínimo que os palestinos estão dispostos à aceitar, e vice-versa". Você concorda com essa declaração?

A.C.: É uma declaração que eu acho que sim, que você pode dizer que é válida, e mais do que isto, a gente nunca teve um governo palestino tão disposto a oferecer e um governo israelense tão não disposto a conceder. Então temos uma total assimetria hoje. É difícil imaginar um cenário pior, apesar de a gente saber que pode chegar lá. 
R.M.: Em sua visão, você diria que o fator confiança seja decisivo? Quão importante você julga os lados confiarem na negociação e no interlocutor presente?

\section{A.C.: É essencial.}

R.M.: E como você vê a falta de confiança alegada por Israel em negociar com os palestinos? Por exemplo, argumenta-se que o Hamas é um grupo terrorista e que não se pode dialogar com tal interlocutor.

A.C.: Bom, isto é um subterfúgio. Israel é perfeitamente capaz de negociar com o Hamas. Veja, por que que eu digo que é um subterfúgio? Porque o governo israelense toda vez que se vê próximo de uma situação, de um governo de união nacional - e isto já aconteceu três vezes de maneira muito concreta no passado, uma vez foi agora em 2014 e outras vezes em 2005 e 2008 -, então as três vezes em que o governo israelense se viu próximo de estar numa situação onde seria chamado à decidir negociar ou não negociar, de fato, ou seja, conversar ou não conversar com um governo que tivesse a participação do Hamas, algum evento bastante suspeito de boicote à aproximação ao governo de união nacional aconteceu. E porque eu digo que tudo indica que seja um subterfúgio, não só por isto, e eu vou explicar melhor isso, mas também por causa da maneira como o governo israelense tratava o partido do Yasser Arafat e o próprio Yasser Arafat na década de 1970. Quer dizer, o Fatah era chamado de terrorista, o argumento para não negociar com o Fatah era ele ser terrorista, e o Yasser Arafat, terrorista. Até que finalmente começaram as negociações de Oslo e nelas o governo israelense não aceitou ainda a participação de Arafat, mas a OLP participou, e depois de um tempo começaram as negociações diretas com Arafat, e foi possível chegar a um acordo, que foi Oslo - que não foi implementado, mas é uma outra história. A história da não implementação do Acordo de Oslo é um caso em si. Então você passa de um discurso de demonização de seu oponente como argumento para não conversar com ele, e quando se conversa aquele grupo de repente então... Tudo bem que ele anunciou que deixava as armas, mas por que anunciou que deixava as armas? Porque havia um contexto em que julgou favorável para isto. 0 Hamas, quantas vezes já não indicou que conversaria com Israel? Já indicou várias vezes. Lembrando que o Hamas é um grupo, é um partido, que tem sua ala militar, sua 
milícia, mas é muito amplo, lembrando que o Hamas não tem uma voz só, tem diferentes lideranças. Mas mesmo levando isto em conta, tivemos já alguns sinais do Hamas de que ele estaria favorável e já houve inclusive períodos bastante longos de seis meses, de vários meses, de cessar fogo com Israel que funcionaram perfeitamente. Quer dizer, o Hamas já mostrou ser um interlocutor possível, um interlocutor até mesmo confiável, em segurar militantes mais "incontroláveis" ou qualquer coisa dentro da Faixa de Gaza, de assegurar a fronteira entre Israel e Gaza. E por que é que então Israel continua dizendo que [o Hamas] não é um interlocutor possível e continua boicotando toda tentativa de união do Hamas com o Fatah? Me parece que a conclusão lógica é uma falta de vontade política de negociar. O problema não é o interlocutor. Talvez até a gente encontre problemas no interlocutor, mas antes de se chegar nisso você tem uma falta de vontade política de negociar, e que a história, toda cronologia, sequência e interpretação delas demonstram.

R.M.: Hoje em dia como você vê o papel dos EUA como mediador ou possível mediador nas negociações entre israelenses e palestinos?

A.C.: Os Estados Unidos têm sido o negociador exclusivo. E em grande parte um negociador pouco apto a criar as condições de um equilíbrio de forças que possa levar a um acordo. Ou seja, colocar o seu peso para que um lado ceda e o outro lado também. Mas a gente não pode ignorar que os Estados Unidos vão continuar tendo um papel preponderante. Achar que as negociações num curto ou médio prazo vão poder acontecer sem a mediação dos Estados Unidos não é real. Então é preciso retroagir um pouco e pensar em um quadro mais amplo de preparação destas negociações. Porque nas negociações os Estados Unidos vão estar. E a gente sabe que nas negociações com os Estados Unidos não se tem obtido resultados. Não é vontade de dizer uma coisa ou outra, é a prática.

R.M.: Você vê alguma alternativa então na mediação? Inclusão de novo atores, de países em desenvolvimento, alguns falam dos BRICS ou até mesmo do Brasil? O que você diria sobre os Estados Unidos serem parte interessada ou enviesada nas negociações? 0 envolvimento de novos atores como mediadores tornaria as negociações mais multipolares? 
A.C.: Sim, seria ótimo sugerir outros atores, seria ótimo se houvesse. Por exemplo, por que não pensar na Assembleia Geral da ONU? Por que não pensar em um corpo representado por todos os países, por algo muito amplo? Por que os BRICS seriam? Como justificar os BRICs ou o Brasil como mediador? Não existe uma justificativa, mas algo que parta da Assembleia Geral, formação de algo muito amplo, aí sim encontraríamos uma justificativa. É uma questão internacional, o problema foi criado em grande medida pela ONU, a ONU é responsável e assim por diante. Agora, o problema é como mudar este quadro de negociações. Como retirar a exclusividade de intermediador das mãos dos Estados Unidos? Porque que todos sabem que isto precisa acontecer para se ter um acordo é dado, a questão é como retirar esta participação.

R.M.: Você acha que Israel já está, na prática, definindo suas fronteiras, considerando principalmente a construção do muro, cada vez mais investimentos na construção de assentamentos e a não evolução das áreas A, B e C dos Acordos de Oslo que continuam estagnadas nas mesmas fronteiras, ao invés de terem migrado de Área C para Área B e Área B para Área A até que os territórios palestinos finalmente tivessem territórios contínuos e viáveis?

A.C.: Eu penso que sim, uma análise do período de Oslo até aqui, incluindo as áreas A, B e C, o que foi feito em termos de legislação, leis e acordos com a Autoridade Palestina de transferência da área A, com poderes municipais, o trajeto do muro e os assentamentos... Eu penso que a gente consegue enxergar aí o estabelecimento sim de uma ocupação passo a passo. Agora fronteiras, não seria o muro, o muro não é fronteira alguma. E também acho que existem também muitas correntes dentro de Israel e que passaram pelo poder desde os Acordos de Oslo até hoje e de 2002, com o início da construção do muro, até hoje. Mas de uma maneira geral, a grosso modo, você vê sim a implementação de um projeto, que é um projeto de ocupação, um projeto de delimitação de fronteiras, e aí eu uso "fronteiras" no plural, porque eu não acredito que o projeto de fronteira seja no muro, o projeto que a gente vê é um projeto de ocupação de toda a Cisjordânia, é só olhar o modelo dos assentamentos. Quem está lá sabe que o muro na verdade é imperceptível quase se você for israelense, e ele é uma muralha enorme se você for palestino. Se você for israelense esse muro não é fronteira alguma, e se você for 
palestino você está na verdade encerrado em bolsões territoriais com a ajuda do muro e de outras medidas.

R.M.: Muitos críticos das políticas israelenses costumam comparar a situação do conflito israelo-palestino com o Apartheid, que perdurou na África do Sul de 1948 a 1994. Neste sentido há iniciativas que propõem boicotar e tentar isolar, se não Israel, pelo menos as colônias ilegais e responder economicamente à expansão dos novos territórios ocupados. Como você avalia possíveis boicotes a Israel, sobretudo a campanha de BDS Boicote, Desinvestimento e Sanções?

A.C.: É possível olhar para a campanha de BDS como uma tentativa de parar o crescimento de colônias, como uma tentativa de defender a solução de dois Estados, digamos assim. Se o boicote foi contra produtos das colônias, você coloca uma posição, olha, queremos então a retirada das colônias para que seja possível então a criação de dois Estados. Mas de uma maneira realista, hoje, dado o atraso nas negociações, dado o avanço na construção de colônias, o panorama em aberto que é a questão palestina, é um campo em aberto. Nenhuma solução está sendo implementada, a não ser soluções não declaradas, digamos assim; então dado este quadro de incertezas, eu acho que talvez seja interessante olhar para a campanha de BDS sob um outro ângulo, sob um ângulo que tem mais a ver com a relação com a África do Sul, de uma campanha contra a violação de direitos humanos dos palestinos. E extraindo do quadro de solução de um Estado, solução de dois Estados, que é uma discussão que está tão longínqua hoje, que é uma discussão que vai depender muito do que vai acontecer internamente. Uma solução de um Estado, por exemplo, depende da população palestina e israelense, uma solução de dois Estados também depende de uma série de fatores. Então, talvez o maior potencial da campanha de BDS seja criar realmente um incômodo para qualquer tipo de empresa israelense que esteja operando - nos assentamento ou não, mas pode ser operando nos assentamentos. Este incômodo é muito forte. Na verdade, um BDS bem sucedido, um desinvestimento que aconteça, gera um incômodo bastante grande para a empresa em questão. E ao mesmo tempo, gera um debate de opinião pública do porquê estar acontecendo esta campanha, e, ao mesmo tempo, lembrar que é uma campanha não violenta. Então, no final das contas, temos uma campanha não violenta, única, dentro de um quadro de negociações que também são não violentas, mas que são fracassadas, 
ações diplomáticas que aqui e ali conseguem algum êxito, muito importante, mas como por exemplo a adesão agora da Autoridade Palestina, ou do governo palestino - se reconhecemos o Estado, como o Brasil reconhece - a uma série de conversões internacionais, incluindo o protocolo de Roma que criou o Tribunal Penal Internacional, mas a Palestina não conseguiu ingressar na ONU devido ao veto do Conselho de Segurança. Então você tem um quadro diplomático difícil, que seria a via pacífica, e você tem uma luta armada, conduzida pelo Hamas por exemplo. Assim, a única alternativa a uma via pacífica fracassada, em grande medida, com pouquíssimos êxitos - apesar de importantes - e uma via belicosa, que só traz mais mortes, tanto de israelense como de centenas e milhares de palestinos, esta única terceira via é a campanha de BDS que está no cenário internacional desde 2005. Então acho interessante que esta campanha de BDS pode ser vista como um fator que parte da sociedade civil internacional, comunidades ao redor do mundo de fazer pressão sobre Estados para reverter aquela correlação de forças de que falávamos. Então pouco importa se é contra assentamentos ou não, pode até ser limitada a empresas que estejam atuando nos assentamentos, mas o que importa é enxergar essa campanha como uma maneira de alterar a correlação de forças, através de uma conscientização, campanha internacional e assim por diante, e aí talvez forçar uma mudança no quadro. Esta é uma maneira de ver, otimista, de uma campanha não violenta que possa ter algum tipo de inserção de fato, seja qual for a solução que vier a ser dada para a questão palestina, e que vai depender de muitos outros fatores.

R.M.: Você falou da estratégia belicosa do Hamas, você imagina o Hamas se tornando um movimento exclusivamente político sem o uso das armas? Um partido político tradicional? Ou 'uma vez grupo terrorista sempre grupo terrorista'?

A.C.: Hoje, o Hamas é um grupo, um partido político, que tem seu braço armado que são as Brigadas Qassamistas. O Hamas pode deixar de ser chamado de grupo terrorista. Primeiro, o que é ser grupo terrorista? Depende de quem qualifica o Hamas como grupo terrorista. 0 Hamas pode deixar de ser qualificado como grupo terrorista o dia em que ele for reconhecido como um partido e como composição de um governo. E esta mudança não se faz. E Israel está muito determinado em não fazer esta mudança. Quanto à característica bélica do Hamas, também pode mudar o dia justamente em que ele virar 
governo, já que ele não terá uma milícia, ele forçará negociações para poder ter o direito de ter um exército, como todo país tem um exército, então ele comporá um país, um governo que vai lutar pelo direito de possuir um exército - a gente sabe hoje que a Palestina não tem este direito, segundo os Acordos de Oslo e demais subsequentes. Então esta classificação de grupo terrorista é algo que pode mudar sim, e o próprio caráter bélico do Hamas é um pouco uma simplificação, dizer que "o Hamas é bélico". 0 Hamas tem a sua milícia e sua organização bélica dentro do contexto atual, que pode ser que mantenha, e pode ser que não. Agora, tem uma coisa que não podemos ignorar. 0 Hamas atuou durante a segunda Intifada, principalmente, com métodos de ataques a bomba e atentados a ônibus, a cafés, atentados a bomba dentro de Israel, por exemplo, e que são classificados como terroristas. Isto pode mudar por parte do Hamas? Eu penso que sim; por conhecer profundamente o Hamas? Não. Eu penso que sim pelo que a gente consegue ver dentro de um cenário local de evolução da questão palestina e com base em comparações históricas mais amplas. Tem mais uma coisa sobre o Hamas, existe o Hamas visto pela sua atuação em relação a Israel, ele então luta contra a ocupação israelense com os meios que podemos condenar ou não, e que na verdade eu condeno. Eu condeno toda a luta armada, e acho que não é a via. Atentados e foguetes, mesmo querendo legitimar sua luta por ser contra a ocupação, eu discordo. Eu acho que a luta do Hamas só castiga os palestinos na Faixa de Gaza. Porque acaba justificando ataques que matam 2.000 pessoas em uma operação de 15 ou 20 dias. E a melhor forma de lutar contra a ocupação é através da resistência não violenta. Não é uma declaração vaga, é uma declaração concreta, com base em resistências não violentas que aconteceram durante a primeira Intifada e com base em outros movimentos como, por exemplo, o caso da África do Sul. Então eu acho que a luta armada do Hamas é um atraso na verdade para a questão palestina, não vejo como uma luta que possa avançar na libertação nacional da palestina. Eu acho que hoje a gente vive um momento histórico em que não cabe mais este tipo de luta, temos outros recursos para poder lançar mão e evitar este tipo de situação. Mais uma coisa sobre Hamas mesmo, é que talvez o legado mais difícil e negativo do Hamas não seja a sua desmilitarização, mas sua aceitação dos próprios direitos humanos dos palestinos ali onde ele governa. Porque onde ele governa a população não pode... Eu conheço artistas palestinos que não podem tocar, não podem cantar, mulheres que são extremamente reprimidas, uma população que já é castigada pela ocupação e que também é castigada por um sistema bastante repressivo do Hamas. 
Então o legado mais difícil de combater não vai ser nem a luta armada do Hamas, eu acho que será outro.

R.M.: Falando um pouco sobre os mecanismos de proteção antiterroristas oferecidos por parte de Israel a sua população, alguns analistas acreditam que Israel esteja se fortalecendo, estabelecendo realmente suas fronteiras, protegendo-se contra os terroristas, e que então a população de Israel estaria mais confortável hoje, principalmente com a construção do muro, solidificação dos assentamentos e bloqueios em Gaza. Como você percebe a alegada sensação de maior segurança, proteção e estabilidade dentro da sociedade israelense hoje? Qual o real nível e percepção de segurança dentro de Israel? Ela é diferente da sensação generalizada de insegurança e medo com os ataques terrorista durante a década de 1990 e anos 2000 em ônibus e cafés? Esta atual sensação de proteção e segurança é ilusória?

A.C.: Quem visita Israel - e eu estive lá no início de dezembro de 2014 e também outras vezes - não vê como uma sensação de segurança. O que eu vejo é uma despolitização da sociedade, o que é diferente. Então o muro teve muito efeito, as estradas exclusivas, todo este sistema de ocupação e que inclui uma segregação bastante forte da sociedade desde 2002, quando o muro começou a ser construído até hoje, há uma segregação cada vez maior da sociedade israelense para um lado e palestina para o outro. Esta segregação teve o efeito de despolitizar a sociedade, de jogar o problema para o outro lado do mudo, então a população não vê muito o palestino, em Jerusalém você ainda vê, mas bem menos. Mas não aumentou a sensação de segurança. Eu pelo menos não vejo, inclusive a escalada de tensão que vimos no ano passado revelou justamente isto, e podemos - e eu pude - sentir um nível de tensão muito grande, porque todos sabem que no fundo é possível ultrapassar o muro, passar por caminhos alternativos, se esquivando dos grandes checkpoints, e que Israel, não é, por causa do muro, um país com fronteiras impermeáveis, digamos assim. Então essa sensação de segurança de fato não existe, porque o muro não tem qualquer coisa que ver com a sensação de segurança, tem sim a ver com despolitização. E, a sensação de medo e de insegurança pode ser habilmente fomentada e explorada por governantes israelenses no seio de sua população para capitalizar mais votos em tempos de campanha eleitoral. 
R.M.: Do ponto de vista da política doméstica israelense, é possível observar uma mudança no jogo de forças nas últimas décadas. Nos anos 1970, a autodenominada esquerda trabalhista era hegemônica na política institucional israelense. Contudo, atualmente o número de parlamentares ditos de esquerda no Knesset é bastante fraco, e, mais recentemente, com a consolidação do Likud e da direita israelense a partir de Ariel Sharon a situação no governo mudou significativamente, ou seja, a direita se cristaliza como grupo hegemônico na política israelense, aliada à extrema-direita. Resta hoje à dita esquerda trabalhista aliar-se ao centro para tentar promover suas plataformas. Como você analisa esta mudança na relação de forças dentro da política interna israelense?

A.C.: De fato esta mudança aconteceu. Esta transição e o crescimento de grupos de direita e de extrema-direita em Israel e de grupos religiosos fundamentalistas em Israel é notável, principalmente no que diz respeito aos grupos religiosos há uma clara diferença em relação à fundação do sionismo e em relação à própria fundação de Israel. A diferença é muito notável e tem a ver inclusive com o período em que vivemos, o crescimento de grupos religiosos fundamentalistas, aliás, não somente em Israel, mas também islâmicos, e cristãos também. É uma tendência geral. Também a gente deve lembrar que, em termos de política externa, alguns governos trabalhistas, do período final principalmente, favoreceram políticas que hoje são mais abertamente defendidas pela direita, então às vezes não é tão simples colocar uma linha divisória entre trabalhistas e direita, no que se refere à política externa. No que tange a política doméstica a diferença é mais clara, mas na política externa quando vemos governos trabalhistas - como foi o caso de Ehud Barak durante o início da segunda Intifada construindo assentamentos como nenhum outro governo antes dele, apoiando e permitindo ações de Ariel Sharon que, aliás, ajudaram a detonar a Intifada. Então também não é que fomos de um governo trabalhista para um governo e coalizões mais a direita. Ocorreu uma transição do cenário político como um todo.

R.M.: Como você reage a alguns especialistas no tema que indicam a desproporcionalidade em termos de cobertura e espaço que o conflito israelo-palestino possui na mídia? Alguns deles alertam que o número de civis e combatentes mortos não se aproxima aos números registrados em três anos de conflitos na Síria, a conflitos na África ou mesmo alvos de violência comunal no Brasil. Nisto estaria velada talvez uma 
crítica à mídia internacional no sentido de que Israel não tivesse direito de reagir ao terror palestino e que houvesse uma espécie de perseguição ao Estado de Israel. Como você se posiciona em relação a estas críticas?

A.C.: É bastante frequente esta queixa e eu também já me deparei com esta queixa vindo à tona em debates. 0 conflito israelo-palestino é uma questão onde estão presentes muitas susceptibilidades, porque estão presentes histórias vivas, é uma questão em aberto e que toca fundo nos sentimentos e nas identificações das pessoas, nas perspectivas, nas suas filiações sentimentais, é uma questão muito delicada. Também já vi acontecer, em geral políticos e acadêmicos israelenses apresentam esta perspectiva e esta queixa, do excesso de cobertura da questão israelo-palestina pela mídia. De fato a questão está muito presente na mídia, primeiramente é preciso reconhecer que de fato ela está presente na mídia, mais do que outras questões que talvez levem a mais mortes do que a questão palestina, então talvez se possa dizer que se é para pesar mortes, por que a questão israelo-palestina está mais em evidência? Talvez a outra devesse estar mais em evidência. Mas não é uma questão de pesar mortes, é preciso ver por que a questão palestina está tão presente. Em primeiro lugar ela está ainda atrelada a um trauma europeu que foi o Holocausto. Isso coloca muito a questão judaica em evidência. E quando a gente fala na questão palestina, estamos falando de duas, israelo-palestina. São duas questões nesta relação, a judaica e a palestina. Em primeiro lugar, ela ainda está sob o impacto do Holocausto em termos de atenção e de olhar para o problema. Quer dizer, qual foi o impacto do Holocausto? 0 impacto do Holocausto foi a Europa ignorar que judeus estavam sendo massacrados, mortos, e exterminados, juntamente com outros, nos campos, e quando isto veio à tona líderes e governantes mundiais buscaram a qualquer custo uma tentativa de explicar o inexplicável e justificar o injustificável. E isso criou um impacto muito grande, que, aliás, pesou inclusive nas discussões e nas negociações na ONU que levaram inclusive à partilha da Palestina. Então quando a Palestina foi partilhada na Assembleia Geral da ONU, sem a participação dos palestinos no debate, e com voto contrário dos árabes, isso tudo foi um processo de muita atenção. Aquilo na época foi central, aliás foi central na própria história do mundo, na medida em que havia uma guerra na Europa, depois dessa guerra todo o processo de criação da ONU, a ONU recém criada decide algo tão significativo quanto a partilha da Palestina com voto de todos os países que eram membros na época. Ou seja, a questão 
israelo-palestina foi criada já como uma questão internacional. Você não pode negar que a questão israelo-palestina, ou a questão da Palestina - já que é ela que ainda não obteve sua soberania, sua independência - é uma questão internacional, e, por ser uma questão internacional, ela recebe atenção internacional, e tem que receber. Então somente resumindo, é verdade que ela recebe, e se recebe é porque ela foi criada e existe sob impacto de grandes acontecimentos e por obra de uma atuação internacional - ainda limitada na época, pois ainda eram poucos os países membros da Assembleia, - mas sob atuação internacional. Então ela não tem como deixar de ser foco das atenções mundiais. Segunda questão, ela está no centro de uma região que durante todo o século XX, a partir da década de 1930 principalmente, foi centro das atenções mundiais por causa da extração de petróleo, e todo tipo de medida tomada no Oriente Médio tinha isto em mente, o que acontecerá com a extração do petróleo se aquela ou outra ação for tomada? Inclusive a criação de Israel também está dentro deste quadro. Também tem o interesse econômico, mesmo a Palestina não tendo petróleo, ela faz parte deste interesse econômico e esta divisão do Oriente Médio esteve influenciada por este interesse econômico. Por uma questão política internacional, por uma questão de impacto da Segunda-Guerra Mundial e do Holocausto e por uma questão de economia internacional, a questão israelo-palestina está então no centro do furacão e dos olhos do mundo. Ela está no centro das atenções mundiais pela história da questão israelo-palestina, pelo Holocausto, pela divisão desta terra. Ela é uma questão internacional, foi partilhada internacionalmente e precisa receber atenção internacional.

R.M.: Tanto dentro da Palestina como dentro de Israel existem movimentos políticos e sociais que se opõem ao status quo, as coisas como elas estão caminhando. Como você vê a efetividade e eficácia da ação destes movimentos, tanto israelenses quanto palestinos?

A.C.: É uma pena que estes movimentos da sociedade civil estejam na verdade tão reduzidos em relação, por exemplo, à primeira Intifada. A primeira Intifada foi um período de maior atuação da sociedade nas questões, tanto israelense como palestina. Mas eu vejo como a única centelha de esperança dentro de tudo isto, é o envolvimento das pessoas. E por isto que ações como o muro, de despolitização, o pior impacto do muro é este, é a despolitização, porque a atuação destes grupos é muito importante, é o que pode permitir... Enfim, tudo. Do lado israelense, você tem grupos de defesa dos 
direitos humanos dos palestinos, são vários, eu nem saberia citar todos, tem o B'T selem, Machsom Watch, grupos palestinos dentro de Israel, Peace Now, Zochrot, tem até os Shministim, jovens que não servem no exército, estes grupos são fundamentais em manter, juntamente com os palestinos, o contato com a população palestina, quer dizer, todo o âmbito que puder, por menor que seja a dimensão daquilo naquele momento, mas todo âmbito que puder romper a segregação é precioso, porque a tendência hoje é de segregação cada vez maior e de crescimento da luta armada. Então estes grupos são fundamentais nisso, em manter a ponte, em manter o contato, manter o olhar humano, humanista, manter a possibilidade de crescimento de um verdadeiro movimento de emancipação dentro da região. E os movimentos palestinos idem, o Badil, o Al-Haq, que na verdade acho que existe dentro de Israel, mas é palestino, o Stop the Wall... Tem o prédio do AIC, Alternative Information Center, o Badil que já falei, também existe o Alternative Tourism Group, que também faz um trabalho espetacular, são vários e eu nem saberia agora dizer de cabeça e citar todos. E sem falar nos comitês populares, os comitês populares que estão ali, organizando a população para resistir à construção do muro, à expansão dos assentamentos, vilarejo por vilarejo, e isto é fundamental. Porque, se não for isto, vai ser o que? Esperar a ONU? Impossível! Entrar para a luta armada? É um tiro no pé - ou na cabeça digamos. Então eu não vejo outra alternativa. Recentemente, eu estive em uma conferência do Conselho Mundial de Igrejas, na Palestina, e é impressionante o trabalho que o Conselho Mundial de Igrejas pode fazer, positivo, de conscientização, de trabalho com o turismo religioso para tentar consertar deturpações que acontecem dentro do turismo religioso. Tem inúmeros âmbitos de atuação, que são todos muito importantes. Mas esta atuação do contato entre sociedade civil israelense e palestinos é fundamental, e só acontece por obra destes grupos, ou as vezes por pessoas, muitas vezes jornalistas, pessoas mais atuantes, é muito importante.

R.M.: Para finalizarmos, gostaríamos de questioná-la sobre antissemitismo e islamofobia. Nós tivemos eleições europeias para o parlamento europeu, que refletiram o crescimento da extrema-direita europeia, recentemente o atentado ao museu em Bruxelas e também, não há muito tempo, um atentado nos Estados Unidos, num centro de convivência cultural judaico. Como você avalia o aumento das manifestações de antissemitismo no contexto de hoje? E como explica o aumento dessas manifestações tanto no ocidente e na Europa, onde o antissemitismo é uma ferida recente, mas também 
entre palestinos e árabes, mesmo que tenhamos que fazer uma ressalva e separar antissemitismo de antissionismo?

A.C.: Eu acho que dentro da Europa, em geral, as manifestações de antissemitismo que têm acontecido - e ao que tudo indica até crescido nos últimos anos -, ataques a sinagogas, centros, cemitérios, seja o que for, estão ligados a um crescimento da direita europeia mesmo, que é tradicionalmente antissemita e que atua e tem como objetivo o fomento de bodes expiatórios internos, vários, que também são islamofóbicos. Estes mesmo grupos são antissemitas e são islamofóbicos, muitas vezes não são coerentes em seus discurso, mas pouco importa, porque o que importa é fomentar o sentimento de medo, sentimento de vulnerabilidade da Europa, sentimento de uma Europa ameaçada, digamos, por fora e por dentro por possíveis ameaças tanto externas como internas, então o inimigo dentro de nós, tudo isso, que é típico de um discurso desta extremadireita e que junto com o crescimento dela cresce este sentimento de antissemitismo. 0 antissemitismo nunca deixou de existir na Europa e, junto com ele hoje, cresce a islamofobia, mas depois tocamos nisto. Além deste antissemitismo tradicional, a gente tem bastante sentimento, seja entre árabes, mas principalmente no Oriente Médio, sentimentos de frustração, sentimento de indignação, sentimento de oposição às políticas israelenses contra os palestinos. Este sentimento de indignação com a opressão do povo palestino, este sentimento que vem junto com a ideia de que Israel ao atacar os palestinos, ao massacrar dois mil deles na Faixa de Gaza em menos de um mês e reiteradas vezes, "está nos atacando", porque há um sentimento de irmandade com os palestinos. Então o ataque israelense com os palestinos para os árabes da região e para o Oriente Médio como um todo é visto como um ataque contra ele mesmo, contra todos, porque há um sentimento de solidariedade com estes palestinos. E esta indignação, esta revolta - e nós estamos falando de sentimentos, nós não estamos falando de processos racionais - e esse sentimento muito frequentemente têm a potencialidade, não digo que sempre, mas tem a potencialidade de transbordar para um sentimento contra judeus. Agora eu acho importante olhar para isto historicamente, e entender que antes do século XX não se podia falar de antissemitismo dentro do Oriente Médio ou regiões árabes, não havia perseguição do judeu por ser judeu. Esta é uma característica importante do antissemitismo: não tem como ele escapar desta condição de judeu, portanto não tem como ele escapar da perseguição, este é o antissemitismo. Então o antissemitismo ou a 
perseguição ao judeu dentro do mundo árabe pelo fato de ser judeu nunca existiu antes do século XX e quando o sionismo começou a ser implantado no começo do século XX existem vários escritos e documentos que trazem lideranças árabes, poetas, intelectuais dizendo que há uma diferença entre o projeto sionista - a que eles se opunham - e os judeus que estavam lá há muito tempo e aos quais eles não se opunham. Porque estes intelectuais principalmente faziam questão de enunciar esta diferença: porque já havia uma confusão no começo do século XX, já estava havendo uma assimilação na percepção de muitos entre o projeto sionista e os judeus. Hoje, o Estado de Israel se apresenta como o Estado do povo judeu.

R.M.: Associação esta feita até para fortalecimento do discurso... Existe até um projeto de lei sendo debatido em Israel para aprovar o Estado de Israel como "Estado do Povo Judeu", que inclusive gerou tanta disputa interna que desmantelou o parlamento e a coalizão de governo de Netanyahu.

A.C.: Exatamente. Há por todos os lados, tanto do lado israelense quanto do lado de lideranças muitas vezes mal conduzidas, atrozes até, dentro de mesquitas ou dentro de centros políticos, seja onde for, fazendo esta associação, entre o Estado - que é um Estado, uma entidade política, tem instituições, não pode ser personalizada - e a figura do judeu ou dos judeus. Então essa associação é promovida por vários, pró-israelenses e anti-israelenses, mas a associação é promovida, e a promoção desta associação acontece em detrimento da convivência entre árabes e judeus no Oriente Médio, porque promove a associação entre Estado e etnia judaica. Então podemos falar que hoje o antissionismo seja uma nova face do antissemitismo? Não. Por quê? Porque eu não estou falando que eles são igualáveis, estou falando que ele transborda, estou falando que o antissionismo transborda muitas vezes em ódio aos judeus - pelo simples fato de serem judeus - sem falar que isto vem ao encontro de um antissemitismo que existia na Europa e em outros lugares e que acaba entrando neste caldeirão de confusões, de preconceitos, e de problemas. Agora jamais eu diria que - e quem está fazendo pesquisa como vocês, e quem está neste campo tem sempre vontade de deixar muito claro - que jamais você pode, por este fato, pelo fato de haver um transbordamento, dizer que o antissionismo seja a nova face do antissemitismo. Porque são coisas diferentes, elas se confundem por 
políticas equivocadas, por políticos equivocados, e assim por diante, mas são absolutamente diferentes.

R.M.: Você falou muito rapidamente sobre islamofobia e eu gostaria de voltar um pouco nisto. Aparentemente tem havido uma crescente islamofobia, dentro da Europa, dos Estados Unidos e em Israel. Como você avalia este movimento? Recentemente tivemos reações islamofóbicas com a divulgação do filme sobre Maomé e dois episódios envolvendo charges na Dinamarca e na França. Após o atentado ao Charlie Hebdo, vários muçulmanos foram alvos de islamofobia na Europa e houve relatos que muçulmanos até no Brasil passaram a sofrer ataques. Como você avalia estas manifestações?

A.C.: Eu avalio que a gente não conseguiu ainda superar uma... Vou começar dando um exemplo. Se antes da Segunda Guerra Mundial havia tanto antissemitismo como islamofobia - porque os dois existiam, apesar do antissemitismo estar em muito mais evidência que a islamofobia -, hoje a gente continua vendo a mesma coisa, só que a islamofobia está em maior evidência. Porque tanto o antissemitismo como a islamofobia fazem parte de um mesmo quadro, de um mesmo cenário, que tem como raiz a criação de um inimigo, a criação de um bode expiatório e um sentimento de superioridade inferiorizando o outro, ou seja, e a divisão do mundo, entre Ocidente/Oriente, nós/eles e assim por diante. Antes da Segunda Guerra Mundial e do Holocausto, o antissemitismo estava muito mais em evidência, como eu estava dizendo, mas, somente para darmos um exemplo, quando nos atentamos para o termo em Auschwitz que os nazistas usavam para designar os judeus internos em estado terminal, doentes, que já não pareciam figuras humanas, era "muçulmano". Chamavam os internos judeus em estado terminal de "os muçulmanos". Alias existem depoimentos terríveis de como que este grupo de "muçulmanos" eram indescritíveis, soldados que entraram para libertação do campo dizendo que não conseguiam olhar para estes "muçulmanos", era algo que feria o próprio sentimento de humanidade de qualquer um que estivesse ali, e eram chamados de "muçulmanos", e eram chamados assim porque andavam curvados. E por que justamente o sentimento de outro? O que é o outro? É o judeu, é o muçulmano, é aquele inimigo infiltrado. Com o Holocausto e este choque que foi, e esta necessidade de reparação do mal que foi o Holocausto, passou a crescer, não imediatamente, mas dependendo do período mais ou menos, mas no período atual, a crescer a islamofobia, e 
com características muito semelhantes ao que era o tipo de sentimento antissemita, dizendo que eram infiltrados, que queriam dominar a Europa, e é o tipo de discurso que existe por setores da direita europeia dizendo que os muçulmanos estão infiltrados, que através das mesquitas querem formar uma rede de contatos que irá subverter a população europeia...

R.M.: ... e acabar com os princípios e valores europeus e criar ou resgatar uma suposta identidade endógena europeia, mas que na realidade nunca existiu sem este intercâmbio, já que este trânsito Ocidente/Oriente é histórico e não existe esta purificação do que é ser europeu ou do que é ser francês...

A.C.: Exatamente. A islamofobia hoje tem espantosamente características muito semelhantes ao que era o antissemitismo no período de ascensão do nazismo, por exemplo. Agora, lembrando que quando a gente fala de antissemitismo, antijudaísmo, islamofobia e para entender estes preconceitos e estes sentimentos, temos que olhar para aqueles que geram este sentimento, que não são nem os judeus e nem os muçulmanos. Ou seja, a islamofobia e o antissemitismo existem independentemente do que façam ou possam fazer os muçulmanos e os judeus. É claro que um atentado como o do Charlie Hebdo vai incentivar o sentimento islamofóbico, mas eles existem independentemente, como traços característicos e próprios e gerados pela sociedade europeia, e na verdade no mundo inteiro. Não estou falando somente europeia, mas pode acontecer e acontece nos Estados Unidos, e acontece como vocês estão dizendo no Brasil em graus maiores ou menores devido à história do problema. Mas entender estes preconceitos é preciso olhar para as sociedades que produzem este preconceito, muito mais do que olhar para os alvos deste preconceito, digamos assim. E é o que está acontecendo hoje na Europa com a islamofobia. E é só lembrarmos que os franceses pensam que tem muito mais muçulmano do que tem, de fato, na França, e assim por diante. 